\title{
Presence of both mating types of Ascochyta rabiei in Argentina suggests potential for sexual reproduction
}

\author{
C Crociara ${ }^{1,2}$ (1) $\cdot{\text { L } \text { Valetti }^{1,2} \cdot S \text { Pastor }}^{1,2}$ \\ Received: 3 July 2020 / Accepted: 15 November 2020 / Published online: 19 November 2020 \\ (C) Australasian Plant Pathology Society Inc. 2020
}

\begin{abstract}
The presence of both mating types was tested for in twelve isolates of Ascochyta rabiei in Argentina. A MATspecific PCR assay was performed. Nine of these isolates were identified as MAT1-1 and three of them MAT1-2. This is the first research regarding the mating types of Ascochyta rabiei in the country and suggests that there is a potential for sexual reproduction in Argentina.
\end{abstract}

Keywords Didymella rabiei $\cdot$ Sexual stage $\cdot$ Ascochyta blight

Ascochyta rabiei is a heterothallic ascomycete fungus which causes Ascochyta Blight (AB) of chickpea (Trapero-Casas and Kaiser 1992), one of the most globally devastating diseases for the crop. Since it was first reported in Argentina in 2012 (Viotti et al. 2012) it has caused yield losses of up to $100 \%$ (De Rossi et al. 2018). Until now, only the anamorph has been reported in Argentina and no research has been conducted on the sexual stages of this fungus in that country.

Sexual reproduction of A. rabiei is controlled by a single regulatory locus, the mating type or MAT locus, which has two idiomorphs, either the MAT1-1 or MAT1-2 forms (Turgeon and Yoder 2000; Barve et al. 2003; Ali et al. 2012). For development of teleomorphic state, both mating types must be present. The presence of a single mating type has been reported in several parts of the world (Barve et al. 2003).

It is well known that sexual reproduction contributes to an increase in pathogenic diversity, allowing fungicides resistance or breakdown of host resistance (Peever

C Crociara

crociara.clara@inta.gob.ar

1 Consejo Nacional de Investigaciones Científicas y Técnicas, Unidad de Fitopatología y Modelización Agrícola, Av. 11 de septiembre 4755, Córdoba, Argentina

2 Instituto Nacional de Tecnología Agropecuaria. Centro de Investigaciones Agropecuarias. Instituto de Patología Vegetal. (IPAVE-CIAP-INTA), Av. 11 de septiembre 4755,

Córdoba, Argentina et al. 2004; Pande et al. 2005; Rhaiem et al. 2007; Ali et al. 2012; Sharma and Ghosh 2016; Manjunatha et al. 2018). Moreover, pseudothecia formed on chickpea debris contribute to long-term survival of the pathogen. Its ascospores have an important role as the primary inoculum for the infection and long-distance spread of the fungus (Bayraktar et al. 2007). For these reasons, the aim of this work was to determine if both mating types MAT1-1 and MAT1-2 were present to establish whether sexual reproduction could occur in Argentina.

Twelve single spore isolates of A. rabiei were obtained from symptomatic chickpea plants, collected in fields of Córdoba province, Argentina. Molecular identification was carried out through phylogenetic inference based on the internal transcribed spacer (ITS) using the universal primers ITS1 (5'- TCCGTAGGTGAACCTGCGG-3') and ITS4 (5'-TCCTCCGCTTATTGATATGC-3') (White et al. 1990); the partial sequence of $\beta$-tubulin gene using TUB2Fd ( $5^{\prime}-$ GTBCACCTYCARACCGG YCARTG- $3^{\prime}$ ) and T2 (5'-TAGTGACCCTTGGC CCAGTTG 3') primes (Groenewald et al. 2013; O'Donnell and Cigelnik 1997) and large ribosomal subunit rDNA D1-D2 regions using D1/D2-NL4 (5'-GGTC CGTGTTTCAAGACGG-3') and D1/D2-NL1 (5'-GCAT A TCAATAAGCGGAGGAAAAG-3') primers (O'Donnell 1993). The pathogenicity of the isolates was confirmed by Koch's Postulates. The isolates tested were deposited into the EEA La Consulta INTA (WDCM 904) collection. To verify the presence of both mating types a multiplex PCR assay was performed according to Barve et al. (2003), using the primers Tail5 
Fig. 1 Amplification of MATspecific Multiplex PCR products from 12 random isolates of Ascochyta rabiei. Lanes 1-9: MAT1-1 isolates. Lanes 10-12: MAT1-2 isolates. M: 100-bp molecular weight marker. WC: Water Control

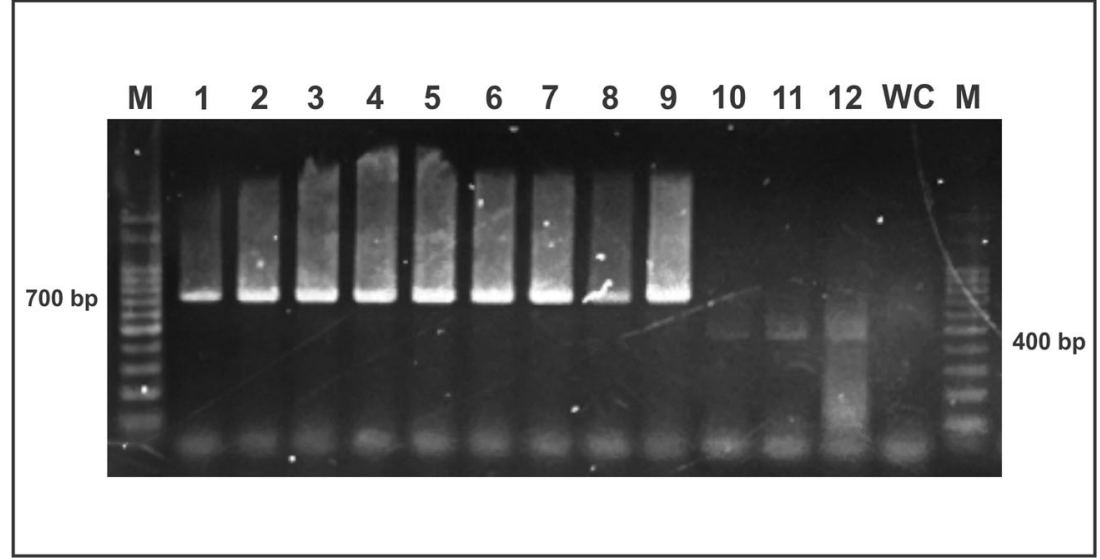

(5'-CGCTATTTTATCCAAGACACACC-3'), SP21 (5'ACAGTGAGCCTGCACAGTTC-3') and Com1 (5'GCATGCCATATCGCCAGT-3').

The results of this assay showed that nine of the analyzed isolates amplified a PCR product of $700 \mathrm{bp}$, which identifies them as being MAT1-1 mating type, and three of them amplified a product of $400 \mathrm{bp}$, which shows that they include the MAT1-2 idiomorph (Fig. 1).

This is the first research on mating types of A. rabiei in Argentina and confirms the presence of both idiomophs. Mating type distribution is one of the important factors that contributes to variation in any pathogen population (Sharma and Ghosh 2016). This fact is a pre-requisite for the teleomorphic state with implications for spread, survival, and control of $A B$ (Manjunatha et al. 2018).

Resistance to fungicides is one of the adaptations that may happen in recombinant populations (Sharma and Ghosh 2016). If this occurred, it would be particularly damaging as few fungicides are legally registered for $\mathrm{AB}$ control in Argentina and AB-resistant commercial varieties are not currently available to the farmers. The presence of a teleomorph in the life cycle of the pathogen contributes to variability within the population, and could lead to development of new pathotypes of A. rabiei (Sharma and Ghosh 2016). Pande et al. (2005) noted that more than 3000 AB-resistant lines had been obtained by ICARDA but most released cultivars succumbed to new pathotypes of A. rabiei. Thus, the possibility of the emergence of recombinant populations is essential information for breeders.

The work described here is a first step towards the study of the sexual stage in Argentina. Further research is needed to monitor the distribution and incidence of both idiomorphs and the teleomorph's occurrence in the Argentinian fields.

Acknowledgments The authors thank Dra. Juliana Iglesias for her valuable contributions in the manuscript's writing.

\section{References}

Ali H, Alam SS, Attanayake RN, Rahman M, Chen W (2012) Population structure and mating type distribution of the chickpea blight pathogen Ascochyta rabiei from Pakistan and the United States. Journal of Plant Pathology, 99-108

Barve MP, Arie T, Salimath SS, Muehlbauer FJ, Peever TL (2003) Cloning and characterization of the mating type (MAT) locus from Ascochyta rabiei (teleomorph: Didymella rabiei) and a MAT phylogeny of legume-associated Ascochyta spp. Fungal Genet Biol 39: 151-167. https://doi.org/10.1016/S1087-1845(03)00015-X

Bayraktar H, Dolar FS, Maden S (2007) Mating type groups of Ascochyta rabiei (Teleomorph: Didymella rabiei), the causal agent of chickpea blight in Central Anatolia. Turk J Agric For 31(1):41-46

De Rossi RL, Guerra FA, Lábaque M, Vuletic E (2018). Estrategias de manejo químico de la rabia del garbanzo (Ascochyta rabiei). Notas de Sanidad Vegetal, (1). http://revistas.bibdigital.uccor.edu.ar/ index.php/NSV/article/viewFile/1445/1415

Groenewald JZ, Nakashima C, Nishikawa J, Shin HD, Park JH, Jama AN, Groenewald M, Braun U, Crous PW (2013) Species concepts in Cercospora: spotting the weeds among the roses. Stud Mycol 75: $115-170$

Manjunatha L, Saabale PR, Srivastava AK, Dixit GP, Yadav LB, Kumar K (2018) Present status on variability and management of Ascochyta rabiei infecting chickpea. Indian Phytopathology 71(1): 9-24

O’Donnell KL (1993) Fusarium and its near relatives. In: Reynolds DR, Taylor JW (eds) The fungal holomorph: mitotic, meiotic and pleomorphic speciation in fungal systematics. CAB International, Wallingford, pp 225-233

O'Donnell K, Cigelnik E (1997) Two divergent intragenomic rDNA ITS2 types within a monophyletic lineage of the fungusfusariumare nonorthologous. Mol Phylogenet Evol 7(1):103-116

Pande S, Siddique KHM, Kishore GK, Bayaa B, Gaur PM, Gowda CLL, Crouch JH (2005) Ascochyta blight of chickpea (Cicer arietinum $L$.): a review of biology, pathogenicity, and disease management. Aust J Agric Res 56(4):317-332. https://doi.org/10.1071/AR04143

Peever TL, Salimath SS, Su G, Kaiser WJ, Muehlbauer FJ (2004) Historical and contemporary multilocus population structure of Ascochyta rabiei (teleomorph: Didymella rabiei) in the Pacific northwest of the United States. Mol Ecol 13:291-309. https://doi. org/10.1046/j.1365-294X.2003.02059.X

Rhaiem A, Cherif M, Dyer PS, Peever TL (2007) Distribution of mating types and genetic diversity of Ascochyta rabiei populations in Tunisia revealed by mating-type-specific PCR and random amplified polymorphic DNA markers. J Phytopathol 155(10):596-605 
Sharma M, Ghosh R (2016) An update on genetic resistance of chickpea to Ascochyta blight. Agronomy 6(1):18

Turgeon BG, Yoder OC (2000) Proposed nomenclature for mating type genes of filamentous ascomycetes. Fungal Genet Biol 31(1):1-5

Trapero-Casas A, Kaiser WJ (1992) Development of Didymella rabiei, the teleomorph of Ascochyta rabiei, on chickpea straw. Phytopathology 82(11):1261-1266

Viotti G, Carmona MA, Scandiani M, Formento AN, Luque A (2012) First report of Ascochyta rabiei causing Ascochyta blight of chickpea in Argentina. Plant Dis 96(9):1375-1375. https://doi.org/ 10.1094/PDIS-02-12-0153-PDN

White TJ, Bruns T, Lee SB, Taylor J (1990) Amplification and direct sequencing of fungal ribosomal RNA genes for phylogenetics. In: Innis MA, Gelfand DH, Sninsky JJ, White TJ (eds) PCR protocols: a guide to methods and applications. Academic Press, San Diego, pp 315-322 